\title{
Liquid Stock and Dividend Payment of Non-financial Quoted Companies in Nigeria
}

\author{
Segun Wale Olayinka, ${ }^{1, *}$ Momodou Mustapha Fanneh ${ }^{2}$, Rafiu Oyesola Salawu ${ }^{1}$ \\ ${ }^{1}$ Department of Management and Accounting, Obafemi Awolowo University, Ile-Ife, Nigeria \\ ${ }^{2}$ School of Business and Public Administration, University of the Gambia, The Gambia
}

Received June 30, 2021; Revised November 1, 2021; Accepted November 21, 2021

\section{Cite This Paper in the following Citation Styles}

(a): [1] Segun Wale Olayinka, Momodou Mustapha Fanneh, Rafiu Oyesola Salawu, "Liquid Stock and Dividend Payment of Non-financial Quoted Companies in Nigeria," Universal Journal of Accounting and Finance, Vol. 9, No. 6, pp. 1366-1376, 2021. DOI: 10.13189/ujaf.2021.090615.

(b): Segun Wale Olayinka, Momodou Mustapha Fanneh, Rafiu Oyesola Salawu (2021). Liquid Stock and Dividend Payment of Non-financial Quoted Companies in Nigeria. Universal Journal of Accounting and Finance, 9(6), 1366-1376. DOI: 10.13189/ujaf.2021.090615.

Copyright@2021 by authors, all rights reserved. Authors agree that this article remains permanently open access under the terms of the Creative Commons Attribution License 4.0 International License

\begin{abstract}
Payment of dividends among firms in Nigeria has become irregular and setting an optimal dividend policy has become an herculean issue. Studies in developed countries indicated that stock liquidity influences dividend payout and this has not been well established in Nigeria. Hence, this study examined the effect of liquid stock on dividend payment of fifty (50) non-financial quoted companies in Nigeria between 2012 and 2019. The study employed secondary source of data collection and analysis was done using descriptive statistics and inferential statistics. The study model expressed the effect of Turnover Ratio, Firm Size, Financial Leverage, Cash Holding and Investment Opportunity on Dividend Payment Ratio using OLS Panel Regression. The results based on the random effect model showed that turnover ratio (TOR) which is a proxy for liquid stock accounts for a significant positive influence on dividend payment while other variables showed negative influence except cash and cash equivalent. Based on the above findings, the study concluded that for most of the companies operating in the non-financial sector of the Nigerian economy, the influence of liquid stock on the amount paid as dividend is positive and significant and those firms with more liquid stocks pay higher amount of dividend than those with less liquid stocks.
\end{abstract}

Keywords Dividend Decision, Investors, Liquid Stock, Quoted Companies

JEL Classification: M21, P34

\section{Introduction}

From the existence of companies, dividend policy has been a herculean issue in corporate finance and as such continues to feature in academic literatures from 1950s till date because in real sense it is a crucial issue for quoted companies (Yusuf [22]). The harder one looks at dividend, the more it seems like a puzzle with pieces that just don't fit together (Black [25]). As stated by Saravanakumar [24], the most critical decision that can be faced by firm is the declaration of dividend because of the major role in which dividend plays when it comes to having a great impact on the expansion of the entity with the help of earnings retained and value of the equity shares. Dividend policy is linked to two aspects; the decision to pay or not to pay dividend and the amount of dividend to be paid or dividend payout ratio. The options available to the quoted companies on how to make use of their earnings has given room for a decision problem on what percentage of this periodical income needs to be shared to investors in the form of dividend (Inyiama, Okwo \& Oliver [26]). To support this claim, Nuredin [27] exclaimed that the decision to either plough back earnings in to the operations of the business for expansion purpose or share the earnings among the shareholders has become a quandary being faced by different firms.

However, the interest of those who put their money in the business operations of the entity is to get return to increase their wealth and where this is not realised they may tend to look for alternative means to meet their 
liquidity needs. In the view of many investors, stocks that pay dividend have become more attractive in Nigeria given the almost cultural belief that making returns on investment is the essence of engaging in any investment (Olusola [16]).

Several studies have revealed that dividend payment is retrogressing gradually and becoming an alien in the corporate world (Proshare [17]; Abdulkadir. Abdullah \& Wong [1]; Sawitri \& Sulistyan [19]; Olusola [16]). Also, the lower propensity to pay dividend by quoted companies in Nigeria has been reported by the Nigeria Stock Exchange where it was revealed that a significant number of firms are yet to pay dividend to their shareholders over a given period of times. The investors of these companies who put their financial resources in the expansion of the companies are yet to receive return on their investment. Even those companies who seem to pay dividend are never consistent in such payment as the pattern of dividend payment in Nigeria has been characterised with zigzag behaviour coupled with microscopic amount being paid compared with the level of financial commitments of the investors (Ogundajo, Enyi, Akintoye \& Dada [14]). Although, this may be as a result of the shock of economic meltdown witnessed by the country in the periods reported which propelled the companies to cut-down on dividend payout to investors, so as to build up their retained earnings to weather the recession storm and save their dividend stocks from becoming less attractive (Proshare [17]). Hence, the fall of dividend payment and propensity to pay dividend by companies in Nigeria have become a great issue of discourse.

As a result of this, there have been unending searches by different investors on what should guide their choice in chosen stocks that will meet their investment goal. In the search to address this investors' apprehension, scholars have pondered on what actually influences dividend policy. Some of the studies done in the developed countries and few developing countries by scholars identified "Stock Liquidity" as a major factor which influences dividend payout ratio.

However, these studies concerning the link between stock liquidity and dividend policy are with divergent views. Different opinions have been expressed on the effect or otherwise of stocks liquidity on the decision to pay or not to pay dividend and the amount that ought to be paid. The research works done by Banerjee, Gatchev \& Spindt [2], Griffin [7], Sawitri and Sulistyowati [19] in Indonesia and Michaely \& Qian [12] in China all revealed that inverse relationship exist between stock liquidity and dividend policy while the findings of Cristea and Cristea [28], Ahmed [29], Igan, Paula and Pinheiro [30], Ghorbani [6] and Lee \& Yoon [11] gave a contrary result. More so, the studies of Sterenczak [21] in Poland and Ghodrati and Fini [5] in Iran gave vague results as the link between stock liquidity and firms' propensity to pay dividend depends on the proxy used for stock liquidity.
Despite the findings of different studies on the relationship between stock liquidity and dividend policy, the position has not been well provided for in the extant literature in Nigeria. Major studies carried out in Nigeria so far either examined stock liquidity and other concepts or dividend policy and other concepts (Ujunwa and Salami [31]; Alayekwu and Achugbu [32]; Nurudeen [33]; Salawu and Olayinka [18]; Nwamaka and Ezeabasili [34]; Williams, Duro and Williams [35]; Duke, Ikenna and Nkamare [36]; Egbeonu, Edori and Edori [37]; Simon-Oke and Ologunwa [38]). Therefore, this area remains underexplored in Nigeria.

Apart from the above introductory section, the rest of this study has been divided into five sections. In section two, several theories and studies were reviewed. Section three discusses the methodology, while section four focuses on results. The study is concluded in section five.

\section{Literature Review}

\section{Theoretical Review}

There have been divergent views in the extant literatures on what actually influences dividend policy of an entity. In an attempt to clear the way on this issue, several theories have been developed by different scholars. Some of these theories include: dividend irrelevance theory, bird in the hand theory, agency theory

Dividend irrelevance theory enunciated by Modigliani and Miller (1961) was anchored on the assumption that the way a company treats its dividend decision has nothing to do with value of the firms. Whether dividend is declared or not and the level of amount paid as dividend are of no use when its value is considered. According to progenitors of this theory, the rate of dividend payout by firms either $0 \%$ or $100 \%$ or any other percentage in between will have no implication on the total market value of the firm as such value will remain the same in any of the circumstance. The only factor that influences the market value of a company's shares is the earning it can realise from its business operations in a particular period of time. Another alternative theory of dividend policy which speaks about whether dividend policy is of a necessity is referred to as "Bird in the hand theory". This theory that came into existence through the works of Myron Gordon and John Linter invalidated the assumption of the M\&M dividend irrelevance theory. This theory has a contrary view to that of M\&M theory. The theory of dividend irrelevance is with the claim that it doesn't matter how investors realise returns on their investment either through dividend payment from the companies or through capital gain from sale of their stocks while this view is not welcome by birds in the hand theory as the theory believes that investors are cognisance of the present dividend paid by the company compared 
with capital gain that is full of uncertainty.

Agency theory addressed the conflict of interest that normally occurs between the management and investors of an organisation. The essence of agency theory is the hunger for the actualisation of personal goals by the agents put in control of the affairs of the organisation at the expense of the principal who are the company's risk-bearers. Hence, the heart-beat of the theory is to make it a point of duty for the managers to work for the maximisation of the shareholders' wealth and their general well-being. In other words, the Agency theory by Ross, Westerfield and Jordan [39] as cited by Olang, Akenga and Mwangi [15] argued that payment of high dividend can help to solve the incessant conflict of interest that normally occur between shareholders and managers.

\section{Empirical Review}

Several studies have been conducted in the developed and developing countries on stock liquidity and dividend policy but with divergent views.

Muhammad, Muhammad and Muhammad [13] found out the impact of the trio of corporate governance, investors' confidence and stock liquidity on dividend policy of companies quoted on the Pakistan Stock Market for six years from 2010-2015. The authors gathered data from the annual report of all listed companies in Pakistan except those whose data are not available as at the time of the research work. The outcomes of the analysis through the use of pooled OLS model gave the indication that in the decision to pay or not to pay dividend by firms, the extent of the liquidity of a stock matters a lot. This assertion implies that what to be declared and paid as dividend by companies will be greatly dependent on the liquid stocks of such companies concerned. In the work of Kim [10] on Korean Corporation where liquid stock was measured with turnover rate, the existence of inverse relationship amidst liquid stock and propensity to pay dividend was established.

In the same vein, Michaely and Qian [12] contributed to the dividend literature by providing cleanly identified and robust empirical evidence of how liquid stock impacts the amount paid as dividends by firms. This was done by gathering data from the "Chinese Security Market Analysis and Research (CSMAR) Database" coupled with the annual reports of all non-financial companies trading their stocks on the floor of stock exchange market in China during the periods 2000 to 2012. The result of the study indicated that as the liquidity of stock of firms increase, there will be reduction in the dividend payment by such firms. The reduction will mostly be felt by those companies with higher level of liquid stock coupled with investors of those companies who are in need of cash. This means that increase in stock liquidity will propel investors with high liquidity demands to market their individual shares to get such liquidity.
Similarly, Sterenczak [21] carried out a hypothesis test on whether those firms in which their stock is characterised with low liquidity status are prone to disburse larger amount of money as dividend to their shareholders compared with those with more stock liquidity. The study considered those firms trading on the floor of stock exchange in Poland for the periods 2011-2015. The peculiarities of some firms such as insurance, banks and companies with negative book value of equity (due to one of the control variables) gave room for their exclusion in the study. The Firms' financial data used for the study were gathered from database of Notoria Serwis while Amihud illiquidity ratio was computed through the data gotten from the archives of session results provided by Warsaw Stock Exchange. Tobit model was used to model the influence of liquid stock on the payout level. The result shown the effect of liquidity ability of stock on the extent of cash dividend paid by different companies although the impact is not significant.

Also, the study carried out by Lee and Yoon [11] with the view to explore the level of interaction between liquidity status of stocks of Korean Corporations and their payout policies exposed the inability of liquidity hypothesis to give a better picture of the dividend policies of those companies quoted on KOSDAQ market. More so, the liquidity strength is observed to be very weak especially when the firm-year observations with non-negligible dividend payments are involved. This result is inconsistent with the existing literatures favouring the potency of stock liquidity when dividend payout policy is concerned with respect to firms in Korea. Ebrahim and Rabab [3] in their research work investigated the dynamic interaction among payout policies, stock liquidity and price in formativeness. The study that covered the periods of seventeen years (1996-2013) sampled different firms situated in UK. The findings revealed the features of shares that pay dividend regularly. Such stocks are known for lower bid-ask spread and a lesser ratio of illiquidity while non-dividend payers' stocks have opposite features. In other words, more liquid stocks pay higher amount of dividend than those stocks with less liquidity.

Also, Szymanska [40] in a study conducted with sample of selected firms quoted on the Warsaw Stock Exchange covering the periods 2000 to 2012, examined whether a decision taken in a given year to declare or not to declare dividend by firms is influenced by the liquidity of the stock of such firms or otherwise. The discoveries of the study revealed the non-existence of any association amidst the decision taken by firms to decide on payment of dividend and the liquidity of stock of such firms. In a similar study, Jiang, Ma and Shi [9] exclaimed that companies with more liquid stock pay more dividend than their counterparts with less liquid stock. More so, the study of Sebastian-Kuhlmann [20] carried out in Europe to ascertain the influence of stock liquidity on dividend 
changes added to the existing literatures which support the assertion that the payment of dividend either high amount or low amount is dependent on the liquidity altitude of the stocks. As a result of this, the analysis done through different statistical techniques in the study agreed to the claim that dividend changes in Europe are statistically driven by stock market liquidity. That is, companies are susceptible to either gear up or bring down the amount of their dividends as a result of increase in the degree of stock liquidity.

El-Nader [41] examined the interactions that exist in the consideration of the trio of liquidity, dividends and ownership of stock marketed on the floor of U.K Stock exchange covering the periods of 2002 to 2016. Multifarious variables were used as proxies for liquidity and the data were sourced from Thomson Reuters Data Stream. It was discovered through the study that dividend payment and liquidity are inversely related. This implies that to receive regular dividend, one must invest in stock with less liquidity. Gunawan and Tobing [42] considered the possibility of liquidity, profitability and investment opportunity to propel companies to pay dividend. This was done through data collected from sampled firms trading on the floor of Indonesia Stock Exchange Market. With the study's findings, liquidity, profitability and investment opportunity have positive effect on the decision to pay or not to pay dividend by quoted companies.

Sawitri et al [19] examined the impact of stock liquidity on decision to pay dividend by non-financial firms in Indonesia covering the years 2014-2016, using purposive sampling method. In the study, Amihud illiquidity ratio and share turnover were used as proxies for stock liquidity. The regression analysis was employed to account for the influence of stock liquidity (the independent variable) and control variables consisting of firms size, profitability, leverage, and cash holding on dividend policy as the dependent variable. The result of the study revealed that stock liquidity as proxied by Amihud illiquidity ratio has a negative insignificant effect, while stock liquidity as proxied by share turnover has a negative significant effect, firms size, profitability, leverage and cash holding have a positive and significant effect, while leverage has a negative but insignificant effect on dividend policy. Sequel to this, it was finalised that the degree of a stock's liquidity strength has a great probability to influence the decision of non-financial public firms in Indonesia to pay or not to pay dividend.

Contrary to the above result, the work of Faradisi and Ulpah [43] revealed that stock with high liquidity status has the tendency to instigate the firms of such stocks to pay higher dividend than those firms with low level of stock liquidity. The study made use of the data gathered from the sampled companies in Indonesia for the periods of 2008 to 2017 and the data were analysed using generalized least square panel data method and logistic estimation method. The implication of the result of the study is that rise in the informational effect of stock liquidity will lead to rise in the dividend payments of the companies.

Nguyen [44] in his study on the effect of stock liquidity on dividend payout policy of companies in the Australian market revealed that stock liquidity leads to improvement in dividend payment of firms. According to him, positive relationship exists between stock liquidity and dividend payout which means an increase in liquidity status of stock of a firm will lead to increase in its dividend payment.

\section{Hypothesis Formulation}

$\mathrm{H}_{\mathrm{i}}$ : Stock liquidity influences dividend policy

$\mathrm{H}_{\mathrm{o}}$ : Stock liquidity does not influence dividend policy

\section{Methodology and Data}

The population of this study consists of all non-financial quoted companies in Nigeria for the periods of 2012 to 2019 as released by the NSE in January 2021. The study adopted purposive sampling technique to select firms whose stocks were actively traded on the stock market during the sample periods with relevant data readily available totalling 50 companies. The secondary data used for this study were obtained from audited annual reports and accounts of the selected non-financial companies for the periods of 2012-2019 and these were collected from the Nigerian Stock Exchange. Descriptive statistics such as arithmetic mean, median, standard deviation and skewness were computed to describe values and features that are typical of some variables. Correlation coefficient and Variance Inflation Factor (VIF) were employed to test for the existence of multicollinearity between the predictor variables and predicted variable. Also, Hausman test was carried out to choose between Fixed effect and Random effect.

\subsection{Model Specification}

The study is concerned with the effect of liquid stock on dividend payment of non-financial quoted companies in Nigeria. Liquid stock was proxied with turnover ratio while dividend payment was captured by dividend payment ratio.

Also, some control variables which extant literatures (Malik, Gul, Khan, Rehman \& Khan [45]; Jabbouri [46]; Yusof \& Ismail [47]; Bostanci, Kadioglu, Sayilgan [48]; Ullah, Bagh \& Arif [49]; Yusuf, [22]) have shown to influence dividend policy were introduced to have a robust result. These control variables are:
i. Firm Age
ii. Financial Leverage 
iii. Firm Size

iv. Investment Opportunity

v. Cash Holding

A functional equation that relates liquid stock to dividend payment is specified as follows:

$$
\begin{aligned}
& D P R_{i t}=f\left(T_{O} O R_{i t}, F A G E_{i t}, F I N L E V_{i t}\right. \\
& \left.F_{i t}, I N V O P P_{i t}, C H_{i t}\right)
\end{aligned}
$$

Where: $D P R_{i t}$ represents dividend payout ratio of the companyi in period $\mathrm{t}$;

TOR $_{\text {it }}$ is the turnover ratio of company $i$ at time $t$

FAGE $_{i t}$ is the Age of the company $i$ at time t;

FINLEV $V_{\text {it }}$ is the financial leverage of company $i$ at time $\mathrm{t}$

$\mathrm{FS}_{\mathrm{it}}$ is the firm size of the companies $\mathrm{i}$ at time $\mathrm{t}$
INVOPP $_{\text {it }}$ is the investment opportunity of company $i$ at time $\mathrm{t}$

$\mathrm{CH}_{\mathrm{it}}$ is the amount of cash and equivalent held by the company $\mathrm{i}$ at time $\mathrm{t}$

Also, there is need to build up the linear equation that shows the relationship between liquid stock and dividend payment. This is shown in equation ii below:

$D P R_{i t}=\beta_{0}+\beta_{1} T_{O O R_{i t}}+\beta_{2} F A G E_{i t}+\beta_{3} F I N L E V_{i t}+\beta_{4} F S_{i t}+\beta_{5} I N V O P P_{i t}+$.

$$
\beta_{6} C H_{i t}+\varepsilon_{i t}
$$

Where: $\boldsymbol{\beta}_{\mathbf{0}}$ is the constant term, $\boldsymbol{\beta}_{\mathbf{1}}, \ldots \boldsymbol{\beta}_{\mathbf{6}}$ are the slopes of the regression to be estimated and $\boldsymbol{\varepsilon}_{\boldsymbol{i t}}$ captures the stochastic error term.

A Priori Expectation: The a priori expectation $\boldsymbol{\beta}_{\mathbf{1}}, \ldots \ldots \boldsymbol{\beta}_{\mathbf{6}}$ will be greater than zero.

\subsection{Variables Measurements and Data Sources Chart}

Table 1. Variables Measurements and Data Sources

\begin{tabular}{|l|l|l|l|l|}
\hline VARIABLES & DETONATION & MEASUREMENTS & SOURCES & $\begin{array}{l}\text { EMPIRICAL } \\
\text { REFERENCES }\end{array}$ \\
\hline $\begin{array}{l}\text { Dividend Payment } \\
\text { Ratio }\end{array}$ & DPR & $\begin{array}{l}\text { Amount of dividend paid for a share in year t } \\
\text { divided by earnings per share }\end{array}$ & $\begin{array}{l}\text { Audited Annual } \\
\text { Reports }\end{array}$ & $\begin{array}{l}\text { Sawitri \& Sulistyowati } \\
{[19]}\end{array}$ \\
\hline Return on Asset & ROA & $\begin{array}{l}\text { Profit before interest and taxes divided by total } \\
\text { assets }\end{array}$ & $\begin{array}{l}\text { Audited Annual } \\
\text { Reports }\end{array}$ & $\begin{array}{l}\text { Salawu \& Olayinka } \\
{[18]}\end{array}$ \\
\hline Turnover Ratio & TOR & Volume of share traded/share outstanding & $\begin{array}{l}\text { NSE, Fact-books, } \\
\text { Daily official list }\end{array}$ & Banerjee et al. [2] \\
\hline Firm Size & FS & Natural log of market capitalisation & $\begin{array}{l}\text { Audited Annual } \\
\text { Reports }\end{array}$ & $\begin{array}{l}\text { Chowdhury \& } \\
\text { Jannatunnesa [55] }\end{array}$ \\
\hline Firm Age & FAGE & Natural log of firm age & $\begin{array}{l}\text { Audited Annual } \\
\text { Reports }\end{array}$ & $\begin{array}{l}\text { Salawu \& Olayinka } \\
\text { [18] }\end{array}$ \\
\hline Financial Leverage & FINLEV & $\begin{array}{l}\text { Ratio of long-term debt to book value of total } \\
\text { assets }\end{array}$ & $\begin{array}{l}\text { Audited Annual } \\
\text { Reports }\end{array}$ & Lee \& Yoon [11] \\
\hline $\begin{array}{l}\text { Investment } \\
\text { Opportunity }\end{array}$ & INVOPP & $\begin{array}{l}\text { Net fixed assetst - Net fixed assetst-1)/ Net fixed } \\
\text { assetst-1 }\end{array}$ & $\begin{array}{l}\text { Audited Annual } \\
\text { Reports }\end{array}$ & $\begin{array}{l}\text { Salawu \& Olayinka } \\
\text { [18] }\end{array}$ \\
\hline Cash Holding & CH & Cash and cash equivalent divided by Total Asset & $\begin{array}{l}\text { Audited Annual } \\
\text { Reports }\end{array}$ & $\begin{array}{l}\text { Lozano \& Caltabiano } \\
\text { [56] }\end{array}$ \\
\hline
\end{tabular}




\section{Results and Discussion of Findings}

The study adopted panel regression technique by taken into consideration the fixed and random effect of the model. Prior to estimation, descriptive statistics and unit root of the variables were obtained. The unit root test was conducted to determine the degree of integration of the variables which formed the basis for adopted model estimating technique. Correlation analysis was also carried out to determine the level of association among the explanatory variables to aid the study in identifying the level of multicollinearity. Table 2 reports the descriptive statistics, while Table 3 reports the correlation analysis, Table 4 captures the panel unit root and Table 5 reports the estimated model.

\subsection{Descriptive Results}

The descriptive statistics on the variables used in achieving the study objective were presented in Table 2. The variables comprises $\mathrm{DPR}_{\mathrm{it}}$ (dividend payout ratio of the company), TOR (the turnover ratio of company), FAGE $_{\text {it }}$ (age of the company), FINLEV (financial leverage of company), FS (firm size of the companies), INVOPP (investment opportunity of company) and $\mathrm{CH}$ (amount of cash and equivalent held by the company).

The average DPR of the sample firm stood at -0.0689 with median value of 0.2212 and maximum value of 14.8794. The least value of DPR was 230.26. The variable exhibited negative skewness and leptokurtic distribution. TOR report an average of 0.2336 and median of 0.1139 . It exhibited positive skewness. More so, reported average age of the firm stood at 51.65 years with 55 years median value. The value of -0.137 depicted that firm age of the firms exhibited negative skewness. The average values of FINLEV, FS, INVOPP and CH were 0.222982, 8.646918, -5660.387 and 0.090336 with standard deviation of $0.544551,1.924883,111495.3$ and 0.358281 respectively.

Jarque-Bera is test statistics for testing whether a series is normally distributed or not and it measures the difference of the skewness and kurtosis of the series with those from normal distribution of all the DPR drivers data series. Their Jarque-Bera statistics with their probability values less than 0.05 (i.e. $\mathrm{p}<0.01$ ) suggested that the null hypothesis of normality in the distribution was rejected.

Table 2. Descriptive Statistics

\begin{tabular}{cccccccc}
\hline & DPR & TOR & FAGE & FINLEV & FS & INVOPP & CH \\
\hline Mean & -0.068938 & 0.233639 & 51.65750 & 0.222982 & 8.646918 & -5660.387 & 0.090336 \\
Median & 0.221250 & 0.113987 & 55.00000 & 0.116142 & 8.633679 & -0.052803 & 0.041879 \\
Maximum & 14.87945 & 9.162022 & 103.0000 & 8.958422 & 12.03145 & 7.221541 & 5.469133 \\
Minimum & -230.2625 & 0.000000 & 8.000000 & 0.000000 & 0.000000 & -2196203. & -1.982866 \\
Std. Dev. & 11.86436 & 0.556829 & 20.11945 & 0.544551 & 1.924883 & 111495.3 & 0.358281 \\
Skewness & -19.08012 & 11.34275 & -0.137703 & 11.59732 & -0.640401 & -19.62148 & 7.847651 \\
Kurtosis & 370.9770 & 173.2874 & 2.454423 & 175.7890 & 4.522372 & 386.0026 & 137.3835 \\
Jarque-Bera & 2189813. & 478347.5 & 6.225049 & 490103.8 & 63.98880 & 2396401. & 296698.0 \\
Probability & 0.000000 & 0.000000 & 0.044489 & 0.000000 & 0.000000 & 0.000000 & 0.000000 \\
Observations & 384 & 389 & 400 & 387 & 388 & 388 & 389 \\
\hline
\end{tabular}

Source: Authors’ Computation, 2021 


\subsection{Correlation Matrix}

The correlation analysis examines the level of association among the explanatory variables in order to detect the likelihood of multicollinearity among the independent variables. Table 3 shows the correlation result between $\mathrm{CH}$ and FS to be -0.1199 . Although, significant correlation exists between $\mathrm{CH}$ and FS, the degree of the association is weak and cannot lead to the problem of multicollinearity. Moreover, it was discovered that no other statistically significant correlation among the independent variables at $5 \%$ level of significance except the weak association between $\mathrm{CH}$ and FS. Weak correlation was observed between some independent variables and the dependent variable (DPR). This is a good thing because it is a pointer to how the variables affect the dependent variable. It was discovered that FINLEV had negative relationship with DPR at 5\% level of significance. TOR also report weak positive correlation with DPR. This revealed that independent variables were independent of each other and implied that the variables can be included in regression analysis as independent variables using Ordinary Least Square (OLS) technique of estimation without obtaining spurious results.

Table 3. Correlation Matrix

\begin{tabular}{|c|c|c|c|c|c|c|c|}
\hline \multicolumn{8}{|c|}{ Correlation } \\
\hline Probability & DPR & TOR & FAGE & FINLEV & FS & INVOPP & $\mathrm{CH}$ \\
\hline \multirow[t]{2}{*}{ DPR } & 1.000000 & & & & & & \\
\hline & ----- & & & & & & \\
\hline \multirow[t]{2}{*}{ TOR } & 0.0139 & 1.0000 & & & & & \\
\hline & $(0.0168)$ & ----- & & & & & \\
\hline \multirow[t]{2}{*}{ FAGE } & -0.0047 & 0.0297 & 1.0000 & & & & \\
\hline & $(0.9266)$ & $(0.5626)$ & ----- & & & & \\
\hline \multirow[t]{2}{*}{ FINLEV } & -0.0571 & -0.0795 & -0.0743 & 1.0000 & & & \\
\hline & $(0.0261)$ & $(0.1211)$ & $(0.1474)$ & ----- & & & \\
\hline \multirow[t]{2}{*}{ FS } & 0.0226 & -0.0701 & -0.0713 & 0.0556 & 1.0000 & & \\
\hline & $(0.6598)$ & $(0.1716)$ & $(0.1646)$ & $(0.2787)$ & ---- & & \\
\hline \multirow[t]{2}{*}{ INVOPP } & -0.0084 & 0.0182 & 0.0506 & 0.0137 & 0.0510 & 1.0000 & \\
\hline & (0.8699) & $(0.7219)$ & $(0.3237)$ & $(0.7884)$ & $(0.3204)$ & ----- & \\
\hline \multirow[t]{2}{*}{$\mathrm{CH}$} & 0.0152 & 0.0411 & -0.0568 & 0.0528 & -0.1199 & 0.0037 & 1.0000 \\
\hline & $(0.7660)$ & $(0.4235)$ & $(0.2681)$ & (0.3034) & $(0.0192)$ & $(0.9412)$ & ----- \\
\hline
\end{tabular}

Source: Authors' Computation, 2021, p-value in parenthesis 


\subsection{Variance Inflation Factor (VIF)}

In order to be sure of the appropriate use of the explanatory variables, the study tested for the existence of multicollinearity among the independent variables using Variance Inflation Factor (VIF) as follow up to the correlation analysis in table 3. Gujarati [23] argues that VIF of any explanatory variable above 10 shows high multicollinearity problem. The result of the VIF using both centred and uncentred indicates that none of the variable report VIF greater than or equal to 10 . This implies that the model does not suffer a multicollinearity problem. This is because only a value of 10 and above could possess incidence of multicollinearity therefore the explanatory variables under consideration are not a perfect linear combination of themselves.

Table 4. Variance Inflation Factors

\begin{tabular}{cccc}
\hline & Coefficient & Uncentered & Centered \\
\hline Variable & Variance & VIF & VIF \\
CH & 2.958906 & 1.088203 & 1.023920 \\
FAGE & 0.001005 & 2.318784 & 1.017722 \\
FINLEV & 3.908953 & 1.432506 & 1.017478 \\
FS & 0.104021 & 2.68310 & 1.031176 \\
INVOPP & $3.00 E-11$ & 1.009099 & 1.006451 \\
TOR & 1.211423 & 1.194487 & 1.013175 \\
C & 12.06430 & 32.03513 & NA \\
\hline
\end{tabular}

Source: Authors' Computation, 2021

\subsection{Panel Unit Root Test}

Panel unit root was conducted using Levin, Lin \& Chu t* and Im, Pesaran and Shin W-stat as reported in table 5. Levin, Lin and Chu t* test the null of unit root by assuming common unit root process among the sample firms, while Im, Pesaran and Shin W-stat test the null of unit root by assuming individual unit root process. The essence of unit root test is to ascertain the degree of integration of the variables. The guideline is that if the p-value is less than $5 \%$ the null hypothesis will be rejected and the alternative hypothesis will be accepted. The result of Levin, Lin \&
Chu $t^{*}$ reject the null of common unit root process, therefore indicated that the variables exhibited common stationarity process across the firms. In the same vein, Im, Pesaran and Shin W-stat reject the null of individual unit root process and concluded that the variables report individual stationary at level. It shows that the variables were of the same order of integration. The results of the tables 5 revealed that the test of null hypothesis for the presence of a unit root was rejected for the variables under consideration which mean that they are stationary at level.

Table 5. Panel Unit Root Test

\begin{tabular}{cccccc}
\hline & \multicolumn{2}{c}{ Levin, Lin \& Chu t* } & \multicolumn{2}{c}{ Im, Pesaran and Shin } & \multirow{2}{*}{ Remark } \\
\hline Variable & Statistics & p-value & Statistics & p-value & \\
CH & -10.4207 & 0.0000 & -3.29758 & 0.0000 & $\mathrm{I}(0)$ \\
INVOPP & -23.7647 & 0.0000 & -2.82747 & 0.0023 & $\mathrm{I}(0)$ \\
FS & -26.6637 & 0.0000 & -7.45673 & 0.0000 & $\mathrm{I}(0)$ \\
FINLEV & -38.0477 & 0.0000 & -2.00170 & 0.0227 & $\mathrm{I}(0)$ \\
FAGE & -4.44401 & 0.0000 & -2.64112 & 0.0103 & $\mathrm{I}(0)$ \\
TOR & -20.7773 & 0.0000 & -3.15209 & 0.0008 & $\mathrm{I}(0)$ \\
DPR & -28.6599 & 0.0000 & -7.57446 & 0.0000 & $\mathrm{I}(0)$ \\
\hline
\end{tabular}

Source: Authors' Computation, 2021

\subsection{Analysis of Regression Result}

Having discovered that the variables were of the same order and also stationary at level, the study adopted panel regression by taking into account the fixed effect and random effect. The study made use of the Hausman test to choose which out of fixed or random effects is appropriate. From the Hausman test shown in table 6, the random effect is more appropriate since p-value of 0.3409 is more than $5 \%$. Serial correlation and Panel Cross-section Heteroskedasticity test were carried out to ascertain the level of robustness of the model. The results of the two tests show that the model is free from the problem of Heteroskedasticity and serial correlation because their respective $\mathrm{p}$-value was greater than 0.05 .

Table 6. Summary Result of the Regression Analysis

\begin{tabular}{|c|c|c|c|c|}
\hline & \multicolumn{2}{|c|}{ Random Effect } & \multicolumn{2}{|c|}{ Fixed Effect } \\
\hline & Coefficient & t-statistics & Coefficient & t-statistics \\
\hline TOR & $0.2427 *$ & 2.7295 & 0.7098* & 2.6853 \\
\hline FAGE & -0.0361 & -0.3855 & -0.0685 & -0.6210 \\
\hline FINLEV & $-2.3176^{*}$ & -2.2684 & $-4.4632 *$ & -2.1520 \\
\hline FS & 0.1769 & 0.7942 & $-0.1388^{*}$ & -2.6722 \\
\hline INVOPP & $-0.0949 *$ & -2.9130 & $-0.0959 *$ & -3.2381 \\
\hline $\mathrm{CH}$ & $0.7273^{*}$ & 2.0862 & 1.5428 & 0.8521 \\
\hline $\mathrm{C}$ & -1.0763 & -0.5959 & 5.2918 & 0.8745 \\
\hline R-squared & \multicolumn{2}{|c|}{0.6647} & \multicolumn{2}{|c|}{0.6320} \\
\hline Adjusted R-squared & \multicolumn{2}{|c|}{0.5312} & \multicolumn{2}{|c|}{0.5147} \\
\hline F-statistic & \multicolumn{2}{|c|}{35.9627} & \multicolumn{2}{|c|}{30.8992} \\
\hline Prob(F-statistic) & \multicolumn{2}{|c|}{0.0000} & \multicolumn{2}{|c|}{0.00000} \\
\hline Hausman test & \multicolumn{4}{|c|}{$1.9096(\mathrm{p}=0.9278)$} \\
\hline Panel Cross-section Heteroskedasticity LR Test & \multicolumn{4}{|c|}{$60.76755(\mathrm{p}=0.1415)$} \\
\hline Serial Correlation test & \multicolumn{4}{|c|}{$-1.162554(\mathrm{p}=0.2450)$} \\
\hline
\end{tabular}




\subsection{Discussion}

Using the random effect model, the result of the OLS revealed that $66.4 \%$ of the variation in DPR was jointly accounted for by the model. Also, the f-statistics of the model shows that the model is statistically significant at $5 \%$ level of significance. TOR had positive relationship with DPR ( $\mathrm{t}=2.7295, \mathrm{p}<0.05)$. It induces the dividend payout ratio of the company by 0.2427 . That is, payment of dividends by companies over time is significantly related to the changes in the liquidity of Stocks. This implies that rise in turnover ratio of the firms will bring about an increase in the firm dividend payout. This is an indication that firms with more liquid stocks pay higher amount of dividend than those with less liquid stocks. This is in agreement with the assumption of asymmetric information theory that states that dividend payment by firms makes inside information available to the market and leads to low level of asymmetric information, hereby leading to higher stock liquidity.

This result is consistent with the works of Ghorbani [6], Fard, Navid and Khanegah [4], Ebrahim and Rabab [3], Jiang, Ma and Shi [9] etc where it was ascertained that the payment of dividend either high amount or low amount is dependent on the liquidity altitude of the stocks. However, the result is contrary to the findings of Gul, Lai, Saffar and Zhu [8], Michaely and Qian [12], Kim [10].

More so, financial leverage ratio of the firm had negative relationship with the dividend payout ratio $(\mathrm{t}=-2.2684, \mathrm{p}<0.05)$. This is an indication of the fact that decline in financial leverage will lead to rise in dividend payout ratio of the company through the inducement of 2.3176 unit increase. In other words, companies whose finance is more of indebtedness may tend to reduce their dividend payments. Cristea and Cristea [28]

Also, it was revealed that firm size $(t=0.7942, \mathrm{p}<0.05)$ has a positive relationship with dividend payment. This result implies that big companies have the likelihood of paying more dividend than the small companies. Large firms have greater opportunities than small firms for expansion through easier ways for fund raising with less dependent on retained earnings for internal financing and thus, pay more dividends. This positive relationship is also supported by the extant literatures (Al-Najjar \& Kilincarslan [51]; Jaara, Alashhab \& Jaara [52]; Ullah, Bagh \& Arif, [49]; Yusuf [22]; Pinto \& Rastogi [53]).

It was also gathered that rise in investment of the firm contribute to decline in the firm dividend payout ratio by 0.0939( $\mathrm{t}=-2.9130, \mathrm{p}<0.05)$. This result indicates an inverse relationship between investment opportunity and dividend payout of firms. The implication of this is that companies with more investment opportunities tend to take advantage of such investment projects by using internal source of fund and hereby cut-down the amount being paid as dividend to their shareholders. On the other way round, companies with little investment opportunities tends to have low morale to retain more but rather prefer to pay more dividends to reduce the agency costs. However, the amount of cash and equivalent held by the company enhance their dividend payout ratio $(\mathrm{t}=2.0862, \mathrm{p}<0.05)$. The implication of this is that companies with enough liquidity are likely to pay more dividend than companies with liquidity problem. The result is consistent with that of Khan and Ahmad [54], Cristea and Cristea [28].

\section{Conclusion and Recommendations}

This research work investigated and dealt with the prevailing issues that concern dividend payout policy and the influence of stock liquidity on dividend policy of non-financial quoted companies in Nigeria. What influence dividend policy which has been the subjects of several studies using different models, techniques and type of data have all been discussed in the recent literatures in both developing and developed economies.

After thorough survey of the financial literatures and the extent of the available empirical evidences on stock liquidity and dividend policy, a number of issues still need to be clarified. For instance, the recent literatures on the association between stock liquidity and dividend policy are with mixed results and studies in this area remain unexplored in Nigeria. This gap in the existing literatures in Nigeria is the focus of this study. Results of the OLS revealed that TOR has positive and significant impact on dividend policy. That is, payment of dividends by companies over time is significantly related to the changes in the liquidity of their Stocks. This implies that rise in turnover ratio of the firms will bring about an increase in the firm dividend payout. This is an indication that firms with more liquid stocks pay higher amount of dividend than those with less liquid stocks.

\section{Recommendations}

From the findings of this study, the following recommendations are made:

a) More attention should be placed by non-financial quoted companies in Nigeria on tactics and strategies that will enhance their profitability and liquidity which will invariably maximize shareholders' wealth through dividend payments.

b) Consistent review should be done on dividend policies of firms because of its intending effect on the ability of the firms to attract investors.

c) Companies should embark on a follow up survey to discover the feelings of the shareholders about the existing payout policy.

\section{REFERENCES}

[1] R. I. Abdulkadir, N. A. Abdullah, W. C. Wong. Dividend 
payment behaviour and its determinants: The Nigerian evidence. African Development Review, Vol. 28, No. 1, pp. 53-63, 2016.

[2] S. Banerjee, V. Gatchev, P. Spindt. Stock Market Liquidity and Firm Dividend Policy. Journal of Financial and Quantitative Analysis Vol. 42, No.2, pp. 369-398, 2007.

[3] Ebrahim, H. A. H. Rabab. Dividend Policy, Stock Liquidity and Stock Price Informativeness. Phd Thesis at University of Bradford, 2017.

[4] H. R. Fard, B. J. Navid, R. Y. Khanegah. Investigating Studying the Relationship between Dividend and Stock Liquidity in Firms Accepted in Tehran Stock Exchange. Journal of Basic and Applied Scientific Research, Vol. 2, No. 8, pp. 421-8428, 2012.

[5] H. Ghodrati, S. R. Fini. Stock Market Liquidity and Firm Dividend Policy: Evidence from Tehran Stock Exchange. Management Science Letters Vol. 4, pp. 1849-1858, 2014.

[6] A. Ghorbani. A Study of the Relationship between Stock Liquidity and Dividend Policy. Faculty of Management and Accounting of Shahid-Beheshti University, Master's Thesis, 2008.

[7] C. H. Griffin. Liquidity and Dividend Policy: International Evidence. International Business Research, Vol. 3, No. 3, pp. 3-9, 2010.

[8] F. A. Gul, K. Lai, W. Saffar, X. Zhu. Political Institutions, Stock Market Liquidity and Firm Dividend Policy. Conference/ Seminar paper presented at Monash University, Sunway Campus, 2015.

[9] F. Jiang, Y. Ma, B. Shi. Stock Liquidity and Dividend Payouts. Journal of Corporate Finance, Vol. 42, pp. 295 314, 2017.

[10] J. W. Kim. The Effects of Stock Liquidity on the Firm's Dividend Policy in Korean Stock Market. Korean Corporation Management Review, Vol. 6, No. 9, pp.133-157, 2016.

[11] J. H. Lee, B. Yoon. Stock Market Liquidity and Dividend Policy in Korean Corporations. The Journal of Applied Business Research, Vol. 33, No. 4, pp. 731-740, 2017.

[12] R. Michaely, M. Qian. Stock Liquidity and Dividend Policy: Evidence from a Natural Experiment. (RM34@Cornell.edu) (meijun.qian@anu.edu.au).pp. 1-43, 2016.

[13] R. Muhammad, S. S. Muhammad, H. B. Muhammad. Investor Confidence, Corporate Governance, Stock Liquidity and Dividend Policy. Journal of Business Studies, Vol. 12, No. 1, pp. 307-327, 2016.

[14] G. O. Ogundajo, P. E. Enyi, I. R. Akintoye, S. O. Dada. Accounting information and dividend payout prediction in Nigerian listed manufacturing firms. Journal of Accounting and Taxation, Vol. 11, No. 1, pp. 9-16, 2019.

[15] M. A. Olang, G. M. Akenga, J. K. Mwangi, J.K. Effect of Liquidity on the Dividend Pay-out by Firms Listed at the Nairobi Securities Exchange, Kenya. Science Journal of Business and Management, Vol. 3, No. 5, pp. 196-208, 2015.

[16] B. Olusola. 84 Companies Fail to Pay Dividend in 5 Years. Leadership Newspaper, 2018. April $3^{\text {rd } h t t p s: / / l e a d e r s h i p . n g / 2018 / 04 / 03 ~}$

[17] Proshare News. Dividend Payments in the Nigerian Capital Market-A view, 5 April, 2013. Retrieved from http://proshareng.com/news/16841

[18] R. O. Salawu, S. W. Olayinka. Stock Market Liquidity and Investment Decisions of Non-Financial Quoted Companies in Nigeria. Journal of Economics and Business Research, Vol. 22, No. 2, pp. 205-226, 2016.

[19] A. N. Sawitri, C. Sulistyowati. Stock Liquidity and Dividend Policy. The International Conference of Organizational Innovation, KnE Social Sciences, pp. 1192-1202, 2018.

[20] M. A. Sebastian-Kuhlmann. The Influence of Stock Market Liquidity on Dividend Changes in Europe. A Doctoral Thesis of Programa de Doctorado en Ciencias Sociales, Escuela Internacional De Doctorado, 2018.

[21] S. Stereńczak. Stock Market Liquidity and Firms' Dividend Policy on the Warsaw Stock Exchange. Research Gate Publication, pp. 1-30, 2016.

[22] R. A. Yusuf. Factors Influencing Dividend Payout Policy of Firms Listed on the Nigerian Stock Exchange. Advances in Economics and Business, Vol. 7, No. 6, pp. 256-265, 2019. DOI: 10.13189/aeb.2019.070602

[23] D. N. Gujarati. Basic Econometric. (4 ${ }^{\text {th }}$ Edition), Tata McGraw-Hill, New Delhi, India.

[24] S. Saravanakumar. Determinants of Corporate Dividend Policy. Asia Pacific Business Review, Vol. 7, No. 2, pp. 25-36, 2011.

[25] F. Black. Towards a Fully Automated Exchange. Financial Analysts Journal, Vol. 27, pp. 28-35, 1976.

[26] E. C. Inyiama, M. Okwo, I. I. Oliver. Dividend Payout Policy Determinants of Selected Listed Brewery Firms in Nigeria: A Meta-Analysis (2000-2013). European Journal of Business, Economics and Accountancy Vol. 3, No.3, pp. 101-118, 2015.

[27] Nuredin, M. Determinants of Dividend Policy of Insurance Companies in Ethiopia, A Thesis Submitted to Addis Ababa University, Ethiopia, 2012.

[28] C. Cristea, M. Cristea. Determinants of Corporate Dividend Policy: Evidence from Romanian Listed Companies. Annual Session of Scientific Papers, pp. 4, 2017.

[29] I. E. Ahmed, I.E. Liquidity, Profitability and the Dividends Payout Policy. World Review of Business Research, Vol. 5, No. 2, pp. 73 - 85, 2015.

[30] D. Igan, Paulaz, M. Pinheiro. Liquidity and Dividend Policy. Princeton University, the University of Houston, 2010

[31] A. Ujunwa, O. P. Salami. Stock Market Development and Economic Growth: Evidence from Nigeria, European Journal of Economics, Finance and Administrative Science, 25, 44-53, 2010.

[32] U. B. Alajekwu, A. A. Achugbu. The Role of Stock Market Development on Economic Growth in Nigeria: A Time Series Analysis. African Review Research Multidisciplinary Journal, Vol. 6, No. 1, pp. 51-70, 2012.

[33] A. Nurudeen. Does Stock Market Development Raise 
Economic Growth Evidence from Nigeria. The Review of Finance and Banking, Vol. 1, No.1, pp. 18- 34, 2009.

[34] O. C. Nwamaka, Ezeabasili. Effect of Dividend Policies on Firm Value: Evidence from quoted firms in Nigeria. International Journal of Management Excellence, Vol. 8, No. 2, pp. 956-967, 2017.

[35] H. T. Williams, A. T. Duro. An Empirical Investigation of the Impact of Dividend Policy on Performance of Quoted Companies in a Developing Economy. Singaporean Journal of Business Economics and Management Studies (SJBEM), Vol. 5, No. 12, pp. 1-14, 2017.

[36] S. B. Duke, N. D. Ikenna, S. E. Nkamare. Impact of Dividend Policy on Share Price Valuation in Nigerian Banks. Archive of Business Research, Vol. 3, No.1, pp. 156-170, 2015.

[37] O. C. Egbeonu, I. S. Edori, D. S. Edori. Effect of Dividend Policy on the Value of Firms (Emperical Study of Quoted Firms in Nigeria Stock Exchange). Journal of Finance and Accounting, Vol. 7, No. 3, pp. 17-24, 2016.

[38] O. O. Simon-Oke, O. P. Ologunwa. Evaluation of the Effect of Dividend Policy on the Performance of Corporate Firms in Nigeria. FUTA Journal of Management and Technology Maiden Edition, pp. 111-120, 2016.

[39] S. A. Ross, R. W. Westerfield, B. D. Jordan. Fundamentals of Corporate Finance (7th ed.). Irwin: Mc-Graw Hill, 2011.

[40] A. G. Szymanska. Impact of a Company’s Dividend Policy on the Liquidity of Shares Listed on the Warsaw Stock Exchange. Financial Internet Quarterly, e-finance, Vol. 13, No. 3, pp. 24-32, 2017.

[41] G. El-Nader. Does Stock Ownership Impact Liquidity and Dividends? Investment Management and Financial Innovations, Vol. 15, No. 3, pp. 111-121, 2018.

[42] F. S. Gunawan, W. R. Tobing. The Effect of Profitability, Liquidity and Investment Opportunities on Dividend Policy. South East Asia Journal of Contemporary Business, Economics and Law, Vol. 15, No. 5, pp. 189-195, 2018.

[43] A. Faradisi, M. Ulpah. Informational Effect of Stock Liquidity on Dividend Payouts: Evidence from Indonesia, Advances in Social Science, Education and Humanities Research, Vol. 558, pp. 658-665, 2019.

[44] T. Nguyen. Stock Liquidity and Dividend Policy: Evidence from an Imputation Tax Environment, International Review of Financial Analysis, Vol. 72(c.), 2020.

[45] F. Malik, S. Gul, M. T. Khan, S. Rehman, M. Khan, M. (2013). Factors Influencing Corporate Dividend Payout Decisions of Financial and Non-Financial Firms. Research
Journal of Finance and Accounting, Vol. 4, No. 1, pp. 35-46, 2013.

[46] I. Jabbouri. Determinants of Corporate Dividend Policy in Emerging Markets: Evidence from MENA Stock Markets. Research in International Business and Finance, Vol. 37, pp. 283-298, 2016.

[47] Yusof, Ismail. Determinants of dividend policy of public listed companies in Malaysia. Review of International Business and Strategy, Vol. 26, No. 1, pp. 88 - 99, 2016.

[48] F. Bostanci, E. Kadioglu, G. Sayilgan. Determinants of Dividend Payout Decisions: A Dynamic Panel Data Analysis of Turkish Stock Market. International Journal of Financial Studies, pp. 1-16, 2018.

[49] K. Ullah, T. Bagh, M. Arif. Factors Affecting Dividend Policy: An Empirical Investigation of Food Sector of Pakistan. Research Journal of Finance and Accounting, Vol. 10, No. 5, pp. 12-28, 2019.

[50] H. R. Fard, B. J. Navid, R. Y. Khanegah. Investigating Studying the Relationship between Dividend and Stock Liquidity in Firms Accepted in Tehran Stock Exchange. Journal of Basic and Applied Scientific Research, Vol. 2, No. 8, pp. 8421-8428, 2012.

[51] B. Al-Najjar, B. Kilincarslan. Corporate Dividend Decisions and Dividend Smoothing: New Evidence from an Empirical Study of Turkish Firms. International Journal of Managerial Finance Vol. 13, pp. 1-38, 2017.

[52] B. Jaara, H. Alashhab, O. Jaara. The Determinants of Dividend Policy for Non-financial Companies in Jordan. International Journal of Economics and Financial, Vol. 8, No. 2, pp. 198-209, 2018.

[53] G. Pinto, S. Rastogi. Sectoral Analysis of Factors Influencing Dividend Policy: Case of an Emerging Financial Market. Journal of Risk and Financial Management, Vol. 12, pp. 1-18, 2019.

[54] F. A. Khan, N. Ahmad. Determinants of Dividend Payout: An Empirical Study of Pharmaceutical Companies of Pakistan Stock Exchange (PSX). Journal of Financial Studies \& Research, pp. 1-16, 2017.

[55] T. A. Chowdhury, Jannatunnesa. Stock Market Investors' Guide to Corporate Dividend Policy: Evidence from Pharmaceuticals and Chemicals Industries in Bangladesh. Asian Journal of Finance \& Accounting, Vol. 9, No. 1, pp. 166-199, 2017.

[56] M. B. Lozano, S. Caltabiano. Cross Institutional Cash Holding and Dividend Policies: Focusing on Brazilian Firms. Journal of Applied Economics, pp. 472014. 